\title{
Nickel(II) removal from wastewater by Microbial Fuel Cell
}

\author{
Yiyang Liu ${ }^{1}$, Liye Shen ${ }^{1}$, Pengfei Song ${ }^{2}$,Dingming Chang ${ }^{l}$, Zhihao Lu ${ }^{1}$, Yongdi Liu ${ }^{1}$, Lankun Cai ${ }^{3}$,
} Lehua Zhang, ${ }^{1, *}$

${ }^{1}$ State Environmental Protection Key Laboratory of Environmental Risk Assessment and Control on Chemical Process, East China University of Science and Technology, Shanghai 200237, China

${ }^{2}$ Department of Biology, Thomas Nelson Community College, Hampton, VA 23666, USA

${ }^{3}$ Shanghai Institute of Pollution Control and Ecological Security, Shanghai 200092, P.R. China

*E-mail: lezhanghua@ecust.edu.cn

doi: $10.20964 / 2019.01 .31$

Received: 4 September 2018 / Accepted: 29 October 2018 / Published: 30 November 2018

The effect of the high standard electrode potential of copper ions on the anode of microbial fuel cells was demonstrated in a previous study. This paper studied the effect of the low standard electrode potential of nickel ions on the anode, including removal efficiency, migration and distribution. More than $95 \%$ of the nickel can be removed in the anode of MFCs (Microbial fuel cells) with influent feed to the anolyte containing $\mathrm{Ni}^{2+}$, while the removal mechanism of nickel ions was chemical precipitation, including approximately $75.5 \%$ in the anode and approximately $15 \%$ in the cathode.

Keywords: Microbial fuel cells; nickel ions; anode; removal mechanism; metal ions

\section{FULL TEXT}

(C) 2019 The Authors. Published by ESG (www.electrochemsci.org). This article is an open access article distributed under the terms and conditions of the Creative Commons Attribution license (http://creativecommons.org/licenses/by/4.0/). 